\title{
Biochemical Studies of the Relationship between lodothyronine 5'-Monodeiodinase and Protein Disulphide Isomerase in Rat Liver
}

\author{
SADAKI SAKANE, INDER J. CHOPRA*, JUNTA TAKAMATSU, \\ AND NAKAAKI OHSAWA \\ First Department of Medicine, Osaka Medical College, Takatsuki \\ 569, Japan, and *Department of Medicine, University of \\ California School of Medicine, Los Angeles, California 90024 , \\ USA.
}

\begin{abstract}
The relationship between type I iodothyronine 5'-monodeiodinase (5'-MD) and protein disulphide isomerase (PDI) was investigated by using a synthetic 18-amino acid peptide (LAP475c), which corresponds to the sequence of amino acids at position 373-390 of PDI including its active site, and anti-LAP475c antibody. Western blot analysis revealed that our anti-LAP475c antibody was highly specific for $57 \mathrm{~K}$ protein in solubilized rat liver microsomal protein (SRLMP) that corresponded to PDI. Anti-LAP475c IgG (1: 100 dilution) precipitated 46\% of 5'-MD. These data suggest that PDI may play a regulatory role in the 5 '-monodeiodination reaction.
\end{abstract}

Key words: Thyroid hormone metabolism, Iodothyronine deiodinase, Protein disulphide isomerase (PDI).

(Endocrinol Japon 39: 461-464, 1992)

3, 5, 3'-TRIIODOTHYRONINE $\left(\mathrm{T}_{3}\right)$, the most active thyroid hormone, is mainly produced in extrathyroidal tissue by enzymic 5'monodeiodination of thyroxine $\left(\mathrm{T}_{4}\right)$ [1]. Previous studies have suggested that 5'-monodeiodinase (5'-MD) enzyme in rat liver microsomes and protein disulphide isomerase (PDI) may share common epitopes [2]. Our recent data suggest that PDI is different from 5'-MD [3]. The relationship between 5'-MD and PDI is still obscure. PDI is a multifunctional protein located in the endoplasmic reticulum which is critical in post-translational modification of proteins [4]. It has been suggested that PDI has two identical, active sites, each comprised of six amino acids (Trp-Cys-Gly-HisCys-Lys) [5]. We prepared a synthetic 18-amino acid peptide (LAP475c), which corresponds to the

Received: June 10, 1991

Accepted: July 3, 1992

Correspondence to: Dr. Sadaki SAKANE, First Department of Medicine, Osaka Medical College, 2-7 Daigaku-cho, Takatsukishi, Osaka 569, Japan sequence of amino acids at position 373-390 of PDI including its putative active site, and obtained an antibody to the LAP475c. This report describes the interaction between 5'-MD and the antiLAP475c antibody.

\section{Materials and Methods}

An 18 amino acid peptide, which included six amino acids in the putative active site of PDI and six amino acids on either side of the active site, was synthesized by the Peptide Synthesis Facility at UCLA by means of the BOC-benzyl strategy and Applied Biosystems Peptide Synthesizer [6] (Fig. 1). Microsomes were prepared from rat liver homogenate as described previously [7, 8]. Solubilized rat liver microsomal proteins (SRLMP) were prepared with $5 \mathrm{mM}$ 3-[(3-cholamidopropyl) dimethylammonio] 1-propanesulfonate (CHAPS; Sigma, St. Louis, MO) in the presence of $10 \%$ glycerol [9]. 


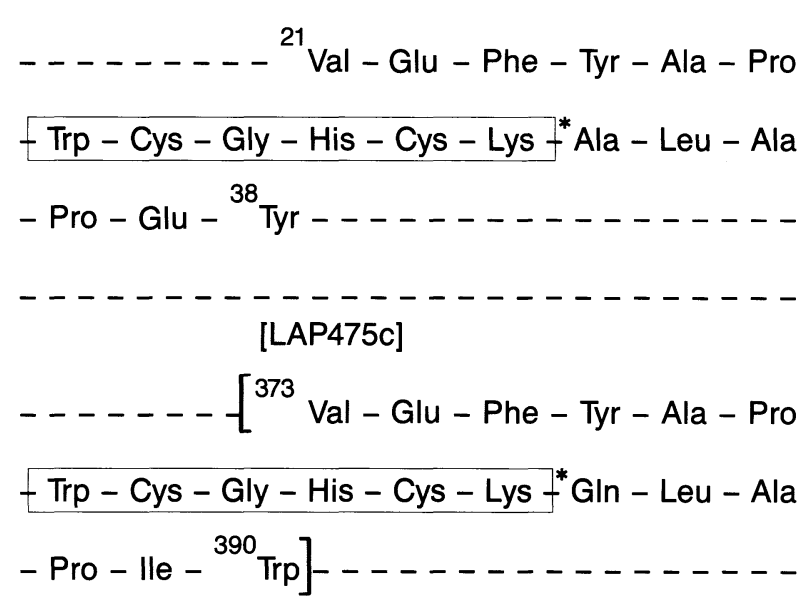

Fig. 1. Preparation of LAP475c, a peptide composed of amino acids in and around the active site of protein disulphide isomerase (PDI). Numbers on the amino acids symbols denote the position of amino acid in PDI molecule. $\square *$, Putative active site of PDI; [ ], LAP475c peptide.

Preparation of anti-LAP475c antibody

LAP475c-bovine serum albumin (BSA) conjugate was prepared with "Morpho CDI"[1cyclohexyl-3-(2-morpholinoethyl) carbodiimide metho-p-toluensulfonate] as described previously [10]. LAP475c-BSA conjugate diluted in saline to a final concentration of $1 \mathrm{mg} / \mathrm{ml}$, was emulsified in an equal volume of complete Freund's adjuvant (Calbiochem, La Jolla, CA). Two $\mathrm{ml}$ of the emulsion, containing $1 \mathrm{mg}$ of LAP475c-BSA conjugate, was injected s.c. at four sites on the back of each of two rabbits. Booster injections were given at 14-day intervals with the conjugate emulsified in incomplete Freund's adjuvant (Calbiolchem). The rabbits were bled 14 days after the fourth injection.

\section{Western blot analysis}

SRLMP were subjected to sodium dodecyl sulfate (SDS)-polyacrylamide electrophoresis (SDSPAGE) under denaturing conditions after treatment of the sample with $1 \%$ SDS and $1 \%$ mercaptoethanol [11]. The gel was electroblotted on a Geenscreen-Plus nylon membrane (Dupont, Boston, MA). The membrane was incubated with an anti-LAP475c antibody dilute $1 / 75$ or antiSRLMP antibody [2] diluted 1/100 followed by incubation with ${ }^{125} \mathrm{I}$-protein $\mathrm{A}$ and autoradiogra- phy [3].

\section{5'-MD enzyme binding assay}

5'-MD enzyme binding assay was performed as described previously [3]. Crude IgG fraction was prepared from sera of normal (control) and immunized rabbits by precipitation with polyethylene glycol (final concentration, W/V, 12.5\%) and the precipitate was reconstituted in phosphate buffer saline ( $\mathrm{pH} 7.4)$ to the original serum volume. SRLMP $(20 \mu \mathrm{g})$ were incubated overnight at $4^{\circ} \mathrm{C}$ with the rabbit IgG solution diluted $1 / 50$ to $1 / 1000$ in $0.1 \mathrm{M}$ Tris- $\mathrm{HCl}, 10 \mathrm{mM}$ EDTA buffer at $\mathrm{pH} 7.6$ (final volume $0.25 \mathrm{ml}$ ). Twenty $\mu l$ of Staphylococcus aureus protein A 10\% (Pansorbin; Calbiochem) was then added and the mixture was incubated for $5 \mathrm{~min}$ at $4^{\circ} \mathrm{C}$. The incubation mixture was centrifuged at $2500 \times \mathrm{g}$ for $7 \mathrm{~min}$ at $4^{\circ} \mathrm{C}$. The supernatant was tested for 5'-MD activity by incubation with ${ }^{125} \mathrm{I}_{-} \mathrm{rT}_{3}(0.6 \mathrm{nM})$ for $10 \mathrm{~min}$ at $37^{\circ} \mathrm{C}$ in the presence of $10 \mathrm{mM}$ dithiothreitol (DTT; Sigma). The results were expressed as the percentage of the control, according to the following equation.

$100 \times$

5'-MD in supernatant (anti-LAP475c IgG) - blank

5'-MD in supernatant (normal rabbit IgG) - blank

The absolute 5'-MD activity in the supernatant of SRLMP incubated with normal rabbit IgG was $4.65 \pm 0.35 \mathrm{pmol} \mathrm{I}^{-} / \mathrm{mg}$ protein $\cdot \mathrm{h}$ (mean \pm SEM, $\mathrm{n}=13)$.

\section{Results}

Figure 2 shows a Western blot analysis of SRLMP with two antibodies, an anti-SRLMP and a specific anti-LAP475c. Anti-SRLMP antibody, which was known to precipitate 5'-MD activity in SRLMP [9], bound some ten proteins in SRLMP (panel 1). Anti-LAP475c antibody bound only one protein in SRLMP; the molecular weight of this protein approximated $57 \mathrm{~K}$ (panel 2). The data on the binding of 5'-MD to anti-LAP475c antibodies are shown in Fig. 3. The IgG (diluted 1: 100) precipitated $46 \%$ of 5 -MD activity; the remaining $54 \%$ of 5'-MD activity was recovered in the supernatant of the incubation medium. An affinity column was prepared with anti-LAP475c and 


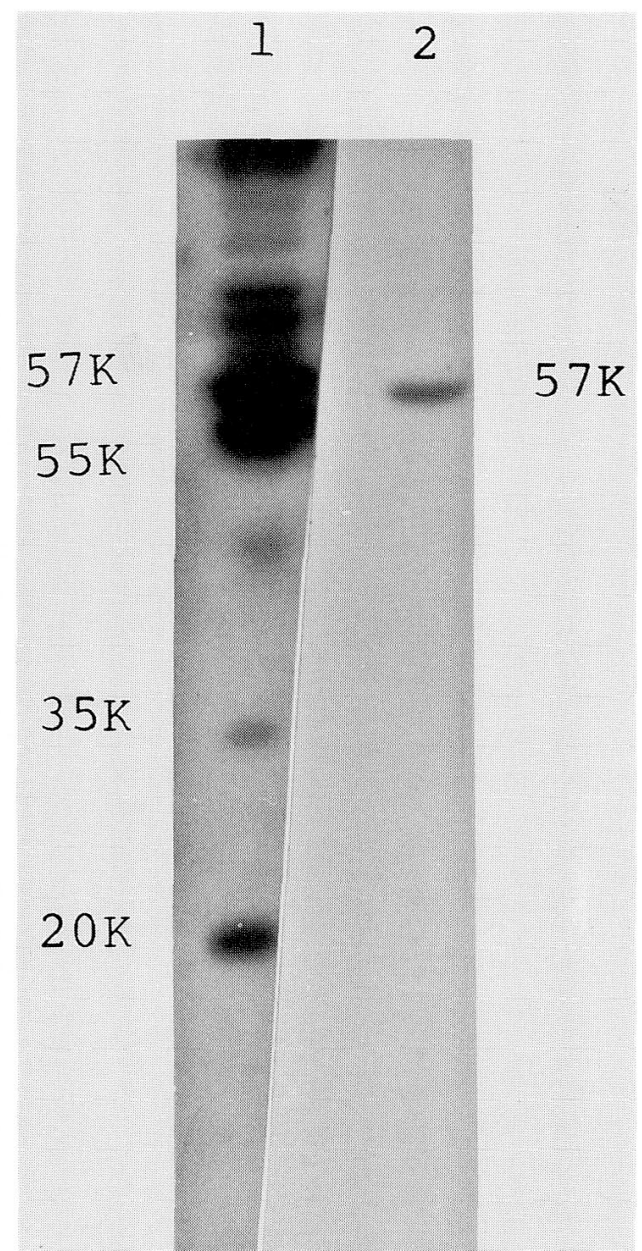

Fig. 2. Western blot analysis of solubilized rat liver microsomal protein (SRLMP). SRLMP were subjected to electrophoresis in a $12 \%$ polyacrylamide gradient gel under denaturing conditions. Proteins were electroblotted on a Geenscreen-Plus membrane. The membrane was incubated with anti-SRLMP (panel 1) or anti-LAP475c (panel 2) antibodies for $1 \mathrm{~h}$ at room temperature. After washing, the membrane was autoradiographed. Each number represents molecular weight in KDa.

cyanogen bromide activated Sepharose $4 \mathrm{~B}$. On the anti-LAP475c immunoaffinity column, 5'-MD active fraction was not obtained (data not shown).

\section{Discussion}

It has been reported that membrane-associated thyroid hormone binding protein is more than $70 \%$ identical to PDI $[12,13]$. In this study, we

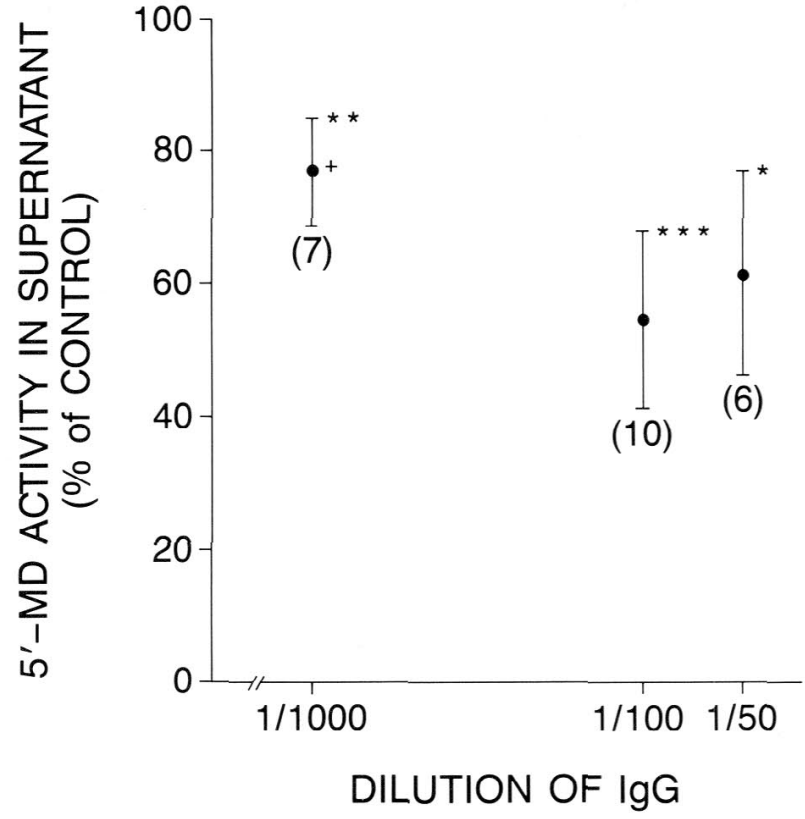

Fig. 3. Absorption of 5'-MD activity in solubilized rat liver microsomal proteins (SRLMP) by an antibody to LAP475c-BSA conjugate (anti-LAP475c antibody). Crude IgG fractions from sera of normal and immunized rabbits were incubated with SRLMP $(20 \mu \mathrm{g})$ overnight. After precipitation of IgG with protein-A 5'-MD activity in the supernatant was measured. Data are expressed as \% of the control (normal rabbit $\mathrm{IgG}$ ) and shown as the mean \pm SEM. Statistical analysis was performed by Student's $t$-test. ( ): Number of experiments. *, $P<0.025 ; * *, P<0.01 ; * * *, P<0.005$.

aimed to study the relationship between PDI and iodothyronine deiodination reaction. Recent studies demonstrate that a $55 \mathrm{~K}$ protein in rat liver microsomes has 5'-MD activity [14] and it is different from PDI [3]. In another study, Berry et al. [15] isolated a cDNA for a putative 5'-MD and suggested that the enzyme protein has a molecular weight of $27 \mathrm{~K}$. The biochemical structure of an active form of 5'-MD enzyme is still unclear. Our anti-LAP475c antibody, which is an antibody to an active site of PDI, was highly specific since it bound just one $57 \mathrm{~K}$ protein in SRLMP (Fig. 2). It may be noted that anti-LAP475c antibody permitted removal from solution of about $50 \%$ of 5 -MD in SRLMP. Previously we showed that a monoclonal antibody to human placental PDI precipitated $-45 \%$ of 5'-MD activity in SRLMP [2]. These data suggest that PDI plays a regulatory role in the 5'-monodeiodination reaction and that the inhibition of 5'-MD by anti-LAP475c antibody may be related to a compromise in this function of PDI. 


\section{Acknowledgments}

We are grateful to Dr. David H. Solomon for his helpful discussion and advice. This study was supported by USPHS grant DK 16155 from the National Institute of Health, Bethesda, MD. USA.

\section{References}

1. Chopra IJ, Solomon DH, Chopra U, Wu S-y, Fisher DA, Nakamura Y (1978) Pathway of metabolism of thyroid hormones. Recent Prog Horm Res 4: 521-567.

2. Boado RJ, Campbell DA, Chopra IJ (1988) Nucleotide sequence of rat liver iodothyronine 5'monodeiodinase (5'-MD): its identity with the protein disulphide isomerase. Biochem Biophys Res Commun 155: 1297-1304.

3. Sakane S, Chopra IJ (1990) Isolation of a hepatic iodothyronine 5'-monodeiodinase (5'-MD) by nondenaturing agarose gel electrophoresis. Endocrinology 127: 2709-2715.

4. Freedman RB, Bulleid NJ, Hawkins HC, Paver JI (1988) Role of protein disulphide-isomerase in the expression of native proteins. Biochem Soc Symp 55: 167-192.

5. Edman JC, Ellis L, Blacher RW, Roth RA, Rutter WJ (1985) Sequence of protein disulfide isomerase and implications of its relationship to thioredoxine. Nature 317: 267-270.

6. Stewart JM, Young JD (1984) Solid Phase Peptide Synthesis. 2nd ed, Pierce Chemical Company, Rockford, Illinois.

7. Chopra IJ (1977) A study of extrathyroidal conversion of thyroxine $\left(\mathrm{T}_{4}\right)$ to $3,5,3$ '-triidothyronine $\left(\mathrm{T}_{3}\right)$ in vitro. Endocrinology 101: 453-463.

8. Maciel RMB, Ozawa Y, Chopra IJ (1979) Subcellular localization of thyroxine and reverse triiodothyronine outer ring monodeiodination activities. Endocrinology 104: 365-371.
9. Boado RJ, Chopra IJ, Flink IL, Campbell DA (1988) Enzyme binding-inhibiting assay for iodothyronine 5'-monodeiodinase (5'-MD) and its application to isolation of complementary deoxyribonucleic acid clones for the 5'-MD in rat liver. Endocrinology 123: 1264-1273.

10. Gharib H, Ryan RJ, Mayberry WE, Hockert T (1971) Radioimmunoassay for triiodothyronine $\left(T_{3}\right)$ : I. Affinity and specificity of the antibody for $\mathrm{T}_{3} . J$ Clin Endocrinol Metab 33: 509-516.

11. Laemmli UK (1970) Cleavage of structural proteins during the assembly of the head of bacteriophage $\mathrm{T}_{4}$. Nature 227: 680-685.

12. Yamauchi K, Yamamoto $\mathrm{T}$, Hayashi $\mathrm{H}$, Koya $\mathrm{S}$, Takikawa H, Toyoshima K, Horiuchi R (1987) Sequence of membrane-associated thyroid hormone binding protein from rat liver: its identity with protein disulphide isomerase. Biochem Biophys Res Commun 146: 1485-1492.

13. Cheng S-y, Gong Q-h, Parkinson C, Robinson EA, Appella E, Merlino GT, Pastan I (1987) The nucleotide sequence of a human cellular thyroid hormone binding protein in endoplasmic reticulum. J Biol Chem 262: 1221-1227.

14. Goswami A, Rosenberg IN (1990) Purification and partial characterization of iodothyronine 5'monodeiodinase from rat liver microsomes. Biochm Biophys Res Commun 173: 6-12.

15. Berry MJ, Lalia B, Larsen PR (1991) Type I iodothyronine deiodinase is a slenocysteinecontaining enzyme. Nature 349: 438-440. 